Tsaqofiya : Jurnal Pendidikan Bahasa dan Sastra Arab

Vol. 3 No. 1, 2021, 46-61

P-ISSN : 2685-7022, E-ISSN : 2685-7103

DOI: $10.21154 /$ tsaqofiya.v3i1.67

\title{
Proses Pembelajaran Berbahasa Arab pada Program BLC (Bilingual School) Kelas VII MTsN Kota Madiun
}

\author{
Zamzam Mustofa \\ Institut Agama Islam Negeri Ponorogo \\ zamzam@iainponorogo.ac.id
}

\section{Abstrak}

Penelitian ini bertujuan untuk mengungkap: (1) Implementasi Program BLC (Bilingual School) (2) Kemampuan berbahasa Arab (3) Problematika Pembelajaran pada Program BLC. Penelitian ini merupakan penelitian lapangan dengan pendekatan kualitatif dan jenis penelitian studi kasus. Data diperoleh dengan teknik dokumentasi, wawancara, dan observasi. Teknik analisis data menggunakan model analisis Miles Huberman, dengan melakukan analisis selama di lapangan secara terus menerus hingga data jenuh. Pengecekan keabsahan temuan dilakukan dengan uji kredibilitas data dengan menggunakan referensi data (bukti autentik data), perpanjangan pengamatan, ketekunan, triangulasi dan diskusi dengan teman sejawat. Hasil dari penelitian menunjukkan bahwa: Pertama, pembelajaran di kelas BLC mengedepankan bahasa sebagai sarana efektif mencetak generasi yang mahir berbahasa. Para siswa mengunakan bahasa Inggris dan bahasa Arab dalam pembelajaranya. waktu pembelajaran dimulai pukul 06.45 sampai dengan pukul 13.30, dilanjutkan dengan Intensif Belajar sampai pukul 15.30 serta 15 menit sebelum pmbelajaran kegiatan English Day dan Arabic Yaumiyyah. Kedua, Pembelajaran bahasa Arab pada program BLC bertujuan untuk mencetak ulama yang intelek dan mampu berinteraksi dengan bangsa luar dengan keterampilan bahasa yang ia miliki. Kemampuan bahasa pada program BLC dianggap cukup bagus terutama pada kelas VII. Ketiga: Problematika pada program BLC, meliputi : Problem Linguistik, yang meliputi: (1) Kurang mengenali bentuk atau tulisan huruf Arab, (2) kesulitan dalam merangkai atau menyambung huruf Arab, (3) siswa kesulitan dalam imla' atau menulis Arab dengan dikte dan Problem NonLinguistik, yang meliputi: (1) siswa (2) latar belakang pendidikan siswa yang heterogen; (3) kurangnya motivasi siswa (4) guru lingkungan (5) madrasah.

Keyword: Proses Pembelajaran, Bahasa Arab, MTsN Madiun

\section{Abstrak}

This research aims to revea: (1) Implementation of the BLC (Bilingual School) Program (2) Ability in Arabic (3) Learning Problems in the BLC Program. This research is a field research using a qualitative approach and the type of case study research. The data were obtained using documentation, interview, and observation techniques. The data analysis technique used the Miles Huberman analysis model, by continuously analyzing the field until the data was saturated. 
Checking the validity of the findings is carried out by testing the credibility of the data using reference data (authentic evidence of the data), extension of observations, persistence, triangulation and discussion with peers. The results of the study indicate that: First: Learning in the BLC programs emphasizes language as an effective means of producing a generation who are proficient in language. Speak using English and Arabic in learning. Teaching time starts at 6:45 a.m. to 1:30 p.m., followed by a Study Intensive until 15:30 and 15 minutes before learning the English Day and Arabic Yaumiyyah activities. Second: Arabic Learning in the BLC programs has the goal to produce intellectual scholars who able to interact with foreign nations by their language skills. As well as the language skills in the BLC programs can be said to be quite good at the VII grade level, . Third: Problematics in the Bilingual school class which includes linguistic problems, are include: include (1) Lack of recognizing Arabic letters or writing, (2) difficulty in stringing or connecting Arabic letters, (3) students having difficulty in imla 'or writing Arabic with dictation and Non-Linguistic problems, that are include: (1) 2) Heterogeneous educational background of students (3) Lack of student motivation (4) Environmental teachers (5) Madrasah.

Keyword : Learning Process, Arabic, MTsN Madiun

\section{Pendahuluan}

Bahasa Arab menarik minat jutaan penduduk dunia untuk mempelajarinya karena berbagai alasan tersebut di atas. Tidak hanya umat Islam, mereka yang non muslim pun juga tertarik untuk mempelajari bahasa Arab. Di Amerika misalnya, hampir tidak ada satu perguruan tinggi Khatolik atau Kristen yang tidak mengajarkan bahasa Arab. Sebagai contoh, Harvard University, sebuah perguruan tinggi swasta paling terpandang di dunia yang didirikan oleh para cendekiawan Protestan dan Georgetown University, sebuah universitas swasta Khatolik. Keduanya mempunyai pusat studi Arab.

Bahasa Arab juga telah di ajarkan di Indonesia. Bahasa ini masuk ke Indonesia bersamaan dengan masuknya agama Islam ke Indonesia. Pada zaman dahulu pengajaran bahasa Arab hanya ditemukan di pesantren atau lembaga pendidikan yang bernuansa islami. Namun sekarang, pengajarannya telah mengalami perkembangan yang sangat pesat. Tidak hanya pada lembaga pendidikan pesanten atau yang berada dibawah naungan. Kementerian Agama saja, akan tetapi mulai merambah pada lembaga-lembaga pendidikan yang sifatnya umum dan juga mereka yang berada di bawah naungan Kementerian Pendidikan Nasional.

Pembelajaran yang efektif dapat diciptakan dengan melakukan inovasi pembelajaran. Salah satunya adalah dengan menggunakan media dalam pembelajaran. Pada zaman dahulu dimana perkembangan teknologi belum 
mengalami perkembangan sepesat sekarang ini, para pengajar menggunakan media sederhana dalam menyampaikan informasi kepada siswa. ${ }^{1}$ Berbagai macam media mereka gunakan dengan tujuan supaya siswa dapat menangkan apa yang mereka jelaskan disamping sebagai inovasi dalam pembelajaran. Bukan hanya hasil belajar memuaskan yang menjadi tujuan utama dalam pembelajaran, akan tetapi juga keberhasilan dalam proses yang dilaksanakan.

Perkembangan teknologi yang menyebabkan revolusi di berbagai aspek kehidupan mempunyai peranan penting dalam kehidupan manusia, begitu juga bagi dunia pendidikan, lebih spesifik lagi dalam pembelajaran. Beragam kemungkinan ditawarkan oleh teknologi untuk meningkatkan kualitas pembelajaran. Di antaranya adalah sebagai sarana peningkatan dan pengembangan kemampuan profesional tenaga pengajar, sebagai sumber belajar dalam pembelajaran, sebagai alat bantu interaksi pembelajaran, dan sebagai wadah pembelajaran.

Dunia informasi menjadi salah satu wilayah yang berkembang pesat dan banyak mempengaruhi peradaban masyarakat. Kondisi perubahan peradaban tersebut juga telah menjadi pemicu terhadap upaya perubahan sistem pembelajaran di sekolah. Kondisi sekolah, senantiasa dituntut untuk terus-menerus mengikuti perkembangan ilmu pengetahuan dan teknologi yang berkembang pesat. Kehadiran teknologi multimedia, bukan lagi menjadi barang mewah,karena harganya bisa dijangkau oleh segenap lapisan masyarakat untuk memiliki dan menikmatinya. ${ }^{2}$ Artinya, sekolah sebagai lembaga pendidikan harus mampu untuk memiliki teknologi tersebut sehingga bisa menjadikannya sebagai media pembelajaran yang menarik, interaktif, dan mampu mengembangkan kecakapan personal secara optimal, baik kecakapan, kognitif, afektif, psikomotrik, emosional, maupun spiritual.

Pemanfaatan teknologi dalam pembelajaran diharapkan akan dapat meningkatkan kualitas pembelajaran serta memperluas jaringan pendidikan dan pembelajaran karena teknologi telah menjadikan ilmu pengetahuan lebih mudah diakses, dipublikasikan dan disimpan. Selain itu pemanfaatan teknologi diharapkan

1 Isop Syafe'i, "Implementasi Media Bahasa Dalam Pembelajaran Mahārat Al-Kalām Berdasarkan Fungsi Media Pembelajaran Menurut Kemp Dan Dayton,” Tsaqofiya: Jurnal Pendidikan Bahasa Dan Sastra Arab 2, no. 2 (2020): 152-67.

2 Siti Fatimah Azzahra, "Penyusunan Kamus Kedokteran Arab-Indonesia Dengan Pendekatan Linguistik Korpus,” Tsaqofiya: Jurnal Pendidikan Bahasa Dan Sastra Arab 2, no. 2 (2020): 168-74. 
pula dapat mengurangi biaya pendidikan, serta memberikan sumbangsih terhadap upaya integritas ilmu pengetahuan.

Dalam pembelajaran bahasa yang menjadi tujuan utama adalah penguasaan kemampuan berbahasa. Kemampuan berbahasa mengacu pada kemampuan yang berhubungan dengan penggunaan bahasa dalam komunikasi nyata. Dengan Kemampuan berbahasa seseorang dapat mengungkapkan fikiran dan isi hatinya kepada orang lain yang merupakan tujuan pokok pengajaran bahasa sebagai suatu bentuk berkomunikasi. Kita mengetahui bahwasanya eksistensi Pembelajaran Bahasa Arab telah berabad-abad umurnya.Makin maju perkembangan jaman dan teknologi makin maju dan beragam pula tujuan pengajaran dan pembelajaran Bahasa Arab. Bahasa Arab seperti bahasa-bahasa lainnya, memiliki empat kemahiran yakni kemahiran menyimak (istimā'), kemahiran berbicara(kalām), kemahiran membaca (qirā'ah) dan kemahiran menulis(kitābah). ${ }^{3}$ Dan ada pula yang mengatakan "jika seseorang menguasai suatu bahasa, secara intuitif ia mampu berbicara dalam bahasa tersebut". Pendapat ini jelas mengindikasikan bahwa kemahiran berbicara (kalām) mengisyaratkan bahwa seseorang mengetahui suatu bahasa.Selain itu, keterampilan berbicara bisa juga digunakan sebagai suatu media untuk belajar. Karena kemahiran ini sangat terkait dengan pelafalan, gramatika, kosakata, diskursus, keterampilan mendengarkan, dan lain lain.Maka Penggunaan metode dan strategi atau teknik yang didasari oleh pendekatan (approach) yang tepat akan berpengaruh terhadap hasil dari tujuan pembelajaran bahasa. ${ }^{4}$

Kecanggihan teknologi memberikan nuansa berbeda dalam proses pembelajaran. Teknologi telah mengubah lokasi belajar yang mulanya hanya berpusat di kelas ke tempat dimana saja siswa ingin melaksanakan kegiatan belajar. Teknologi komunikasi terutama belajar melalui dunia maya (virtual world) dapat diakses dan dimanfaatkan tanpa memandang usia, jarak, lokasi, dan karakteristik pengguna atau user. ${ }^{5}$ Hampir setiap lembaga pendidikan telah dilengkapi dengan sarana prasarana berbasis komputer. Laboratorium bahasa juga telah banyak dimiliki

\footnotetext{
3 Muhammad Ibn Mar'ī al Hazimī, "Daurah Al Shayfiyah Al Tsāniyah Li Mu'alimi Al Lughoh Al 'Arabiyyah Fī Jāmi'at Al Indūnisiyah Wa Al Mudarris Al Singhāliyah, Tadrīs Mahārāt Lughawiyah," Makkah: Jāmi'ah Umu Al Qurā, n.d., 50.

4 Theodore Heubener, "Audio-Visual Techniques in Teaching Foreign Languages," New York: Cambridge University Press, 1960, 5.

5 Dewi Salma Prawiradilaga, "Prinsip Desain Pembelajaran (Instructional Design Principles), Jakarta: Kencana Prenada Media Group," Cetakan Kedua, 2007, 7.
} 
oleh setiap lembaga pendidikan. Apabila dilihat, media pembelajaran bahasa Arab yang ada saat ini sudah cukup memadai dan membantu para pengajar untuk menciptakan suatu kondisi pembelajaran yang efektif. Akan tetapi, masih sedikit dari mereka yang memanfaatkan media yang ada. Mereka tetap bertahan dengan teknik pengajaran masa lampau dan kalaupun menggunakan multimedia yang tersedia hanya sekedar formalitas saja.

Pada perkembanangan Ilmu pendidikan di Madrasah Tsanawiyah Negeri Kota Madiun menekankan pada aspek aspek kemampuan siswa ataupun bakat yang dimiliki. Dengan dibagi Kelas PDIC, Bilingual School, Multi media, Khubbul Qur'an, Olahraga, serta Reguler penerapanya mengunakan Kurikulum 2013, Setiap golongan kelas tersebut mempuyai visi misi masing masing. Jam pembelajaran mulai pukul 06.30 Wib sd 16.00 Wib (PDIC, Bilingual School, Multimedia, Khubbul Qur'an, Olahraga). Sedangkan 06.30 Wib sd 14.00 Wib ( KelasReguler). Hanya Kemampuan yang kecerderdasan yang tinggi yang berhak masuk di kelas PDIC, Bilingual School, PDIC adalah kelas Akselerasi yang di tempuh selama 2 tahun. Sedangakan Kelas Bilingual School adalah program yang menggunakan dua bahasa, Arab dan Inggris.

Kelas Bilingual (BLC) adalah kelas dengan kurikulum 2013 dengan pembelajaran Matematika dan IPA wajib menggunakan Bahasa Indonesia \& Bahasa Inggris serta seluruh mata pelajaran berbasis TI (Teknik Informatika) dan waktu pembelajaran dimulai pukul 06.45 sampai dengan pukul 13.30, dilanjutkan dengan Intensif Belajar samapi pukul 15.30 serta 15 menit sebelum pmbelajaran kegiatan English day hsetiap hari Rabu dan kamis dan Arabic yaumiyyah setiap hari Senin dan Selasa. Dengan sarana Ruang Belajar ber AC, LCD projektor, Laptop kelas, speaker aktif, printer kelas, Hot Spot Area Internet, Perpustakaan Kelas, dan LED TV 32 in. ${ }^{6}$

Menurut Peneliti, pembelajaran di BLC (Bilingual School) ini menarik untuk di amati dan di teleti secara bertahap terkait Implementasinya Analisis Tingkat kemampuan serta problematika pembelajaran yang ada. Apakah sudah memenuhi standar mutu yang ada ataukah masih jauh dari harapan yang meliputi beberapa rumusan masalah: 1) Bagaimana implementasi pembelajaran bahasa Arab kelas VII di Kelas BLC (Bilingual School)?, Bagaimana kemampuan bahasa Arab program kelas BLC (Bilingual School)?, Bagaimana problematika pemerolehan bahasa Arab pada kelas BLC (Bilingual School)?. Berdasarkan alasan-alasan tersebut, maka penulis

\footnotetext{
6 Profil MTsN Kota Madiun
} 
tertarik untuk melakukan penelitian tentang peningkatan pembelajaran bahasa Arab dengan menitikberatkan pada proses pembelajaran yang ada di kelas BLC (Bilingual School).

\section{Metode}

Penelitian ini menggunakan paradigma kualitatif di mana penyajian data dan berbagai keterangan lainnya bersifat deskrptif dan bukan berupa angka. ${ }^{7}$ Ditinjau dari aspek medan penelitiannya, penelitian ini mengalami dua tahap. Tahap pertama adalah penelitian interaktif (lapangan), dan yang kedua adalah penelitian noninteraktif (analisis dokumen). Rumusan masalah I dan II menggiring peneliti untuk melakukan observasi langsung dan wawancara di lapangan dalam rangka mencari data yang akurat. Permasalahan terkait Implementasi pembelajaran bahasa Arab di MTsN kota Madiun yang mana harus dijawab dengan meminta keterangan dari pihak-pihak yang terkait dengan Kegiatan Belajar-Mengajar tersebut, dan juga pengamatan terhadap yang terkait dengan KBM tersebut. Dalam tahap ini digunakan jenis penelitian studi kasus (case study) yang dalam penelitian pendidikan bahasa adalah bentuk penelitian yang mendalam tentang suatu aspek pendidikan bahasa, termasuk lingkungan pendidikan bahasa dan manusia yang terlihat dalam pendidikan bahasa di dalamnya. ${ }^{8}$ Data yang dikumpulkan adalah berupa kata-kata, gambar dan bukan angka-angka. Hal itu disebabkan oleh adanya penerapan metode kualitatif. Selain itu, semua yang dikumpulkan berkemungkinan menjadi kunci terhadap apa yang sudah diteliti. ${ }^{9}$ Di sisi lain, pendekatan kualitatif pada dasarnya berusaha untuk mendeskripsikan gejala sosial secara komperhensif, mendalam dengan jalan mengamati realitas yang ada. Sejalan dengan penelitian bahasa, yaitu dengan menguraikan identitas objek penelitian berupa fakta lingual yang nyata oleh penutur dan bukan fakta lingual yang difikirkannya.

\section{Pembahasan}

\section{Implementasi Pembelajaran Bahasa Arab di Kelas BLC (Bilingual School)}

\footnotetext{
7 P Dr Sugiyono, "Metode Penelitian Pendidikan: Pendekatan Kuantitatif, Kualitatif, R\&D (Cetakan Ke)," Bandung: CV Alfabeta, 2012, 15.

${ }^{8}$ A R Syamsuddin, "Metode Penelitian Pendidikan Bahasa," Bandung: Remaja Rosdakarya, $2009,28$.

9 Moeloeng j Lexi, "Metodologi Penelitian Kualitatif” (Bandung: PT. Remaja Rosda Karya, 2001), 11.
} 
Berdasarkan surat dari Departemen Agama Republik Indonesia Nomor: 156/C4/MN/2007, MTsN Kota Madiun dipercaya untuk melaksanakan Program Rintisan Madrasah Bertaraf Internasional (SBI). Sebagai tindak lanjut program ini, kepala Madrasah mengeluarkan empat kebijakan strategis, antara lain:

a. Pelayanan yang prima (good service)

b. Efektifitas dan efisiensi pengelolaan sekolah

c. Mengembangkan berbagai kecerdasan siswa

d. Mengembangkan kurukulum bertaraf internasional

Melalui keempat kebijakan tersebut, diharapkan visi misi yang diemban MTsN Kota Madiun, yakni : "Terwujudnya Madrasah yang Islami, Unggul, dan Mandiri yang Berbudaya Nasional dan Berwawasan Global pada tahun 2012" dapat tercapai terlaksana sesuai dengan harapan. Berbagai prestasi yang dicapai merupakan hasil kerja keras seluruh warga sekolah (team work) serta apresiasi yang tinggi dari para pendidik. Oleh sebab itu terima kasih kami sampaikan kepada berbagai pihak baik perorangan maupun kelompok, baik instansi pemerintah maupun swasta yang telah memberikan dukungan terhadap kemajuan mutu pendidikan siswa MTsN Kota Madiun ${ }^{10}$ Setelah peneliti mengadakan penelitian berdasarkan hasil uraian danm analisa data yang peneliti peroleh melalui maka wawancara, observasi, dan dokumentasi, dapat disederhanakan dengan beberapa kesimpulan diantaranya, untuk mengkalsifikasikan kelas ini diadakan semancam placemantest sebelum calon peserta didik ini masuk ke sekolahan tersebut. Bekerjasama dengan universitas negeri malang fakultas sosiologi dibantu dosen UM . Diadakanlah tes IQ sebagaimana mengukur tingkat respons anak terhadap suatu pelajaran. Test ini dialakukan mengunakan test potensi akademik dan interview. ${ }^{11}$ teknik ini yang digunakan menjaring calon siswa MTsN Kota Madiun. Kemudian baru diklasifikasokan menurut kemampuan yang ada, Program yang hanya diikuti oleh IQ tinggi adalah Program Akselerasi, Program PDCI dan Program BLC (Bilingual School),12 sedangkan yang IQ yang standar nanti bisa memilih program yang meningkatkan IQ seperti Program MM (Multi Media), Program Khubbul Qur'an, Program Olahraga.

10 Lihat Dokumentasi Tulisan MTsN Kota Madiun

11 Lihat Dokumentasi Profil MTsN Kota Madiun

12 BLC (Bilingual School) menurut penulis disini adalah program yang dibuat oleh lembaga sekolah yang visi dan misinya adalah mengunggulkan bahasa Arab dan bahasa Inggris sebagai bahasa pengantarnya ini ditunjang dengan kegiatan Afalul Yaumiyah dan English Day 


\section{Visi dan Misi Kelas Bilingual Scholl (BLC)}

Kelas ini dibentuk untuk membuat kelas berbasis Bilingual dan mengedepankan bahasa sebagai sarana efektif mencetak generasi yang mahir berbahasa. Berbasis penggunaan bahasa Inggris dan bahasa Arab dalam pembelajaranya kelas ini efektif dan banyak dibidik oleh para siswa. Dalam programnya, siswa dituntut untuk bisa mahir berbahasa baik secara Kalam, Qiroah, Kitabah, Insya' di bahasa Arab. Speking, Reading, Listening, Writing pada bahasa Inggris. ${ }^{13}$

Kelas Bilingual Scholl (BLC) mengunakan Kurikulum 2013 dengan pembelajaran Matmatika dan IPA wajib menggunakan Bahasa Inggris, pelajaran agama mengunakan bahasa Arab dan Indonesia serta seluruh mata pelajaran berbasis TI (Teknik Informatika) dan waktu pembelajaran dimulai pukul 06.45 sampai dengan pukul 13.30, dilanjutkan dengan Intensif Belajar samapi pukul 15.30 serta 15 menit sebelum pmbelajaran kegiatan English Day dan Arabic Yaumiyyah

\begin{tabular}{|c|c|c|c|c|c|c|}
\hline Pukul & Senin & Selasa & Rabu & Kamis & Jumat & Sabtu \\
\hline $\begin{array}{c}\text { 06.45- } \\
07.15\end{array}$ & $\begin{array}{c}\text { Afaalul } \\
\text { yaumiyah }\end{array}$ & $\begin{array}{c}\text { Afaalul } \\
\text { yaumiya } \\
\mathrm{h}\end{array}$ & $\begin{array}{c}\text { English } \\
\text { day }\end{array}$ & English day & $\begin{array}{c}\text { Afaalul } \\
\text { yaumiyah }\end{array}$ & English day \\
\hline $\begin{array}{c}\text { 07.30- } \\
13.30\end{array}$ & $\begin{array}{c}\text { Pembelajaran } \\
\text { Kelas }\end{array}$ & $\begin{array}{c}\text { Pembela } \\
\text { jaran } \\
\text { Kelas }\end{array}$ & $\begin{array}{c}\text { Pembel } \\
\text { ajaran } \\
\text { Kelas }\end{array}$ & $\begin{array}{c}\text { Pembelajaran } \\
\text { Kelas }\end{array}$ & $\begin{array}{c}\text { Pembelaj } \\
\text { aran } \\
\text { Kelas }\end{array}$ & $\begin{array}{c}\text { Pembelajara } \\
\text { n Kelas }\end{array}$ \\
\hline $\begin{array}{c}13.30- \\
16.00\end{array}$ & Al-Qur'an & $\begin{array}{c}\text { Tarjama } \\
\text { h Qur'an }\end{array}$ & $\begin{array}{c}\text { Tarjama } \\
\text { h Kitab }\end{array}$ & $\begin{array}{c}\text { Hafalan } \\
\text { Mufrodat }\end{array}$ & $\begin{array}{c}\text { English } \\
\text { covercati } \\
\text { on }\end{array}$ & \\
\hline
\end{tabular}

Tabel 05 : Jadwal pembelajaran pada program BLC (Bilingual School)14

"Memang setiap hari anak anak digembleng 2 bahasa yaitu Arab dan Inggris mas setiap hari mulai hari senin sd sabtu ditambah dengan intensif pagi namun penerepanya atau impelmentasinya masih $65 \%$ belum mencapai target sempurna mahir berbahasa beberapa anak ada yang intelllegensia-nya bukan di linguistik (bahasa)"15 "Memang kelas ini di bentuk sesuai keginginan wali murid mas dan setiap tahun kita ke pare selama 2 minggu untuk memperkuaat bahasa Arab dan Inggris sudah ada MOU dengan pihak sana"16

\footnotetext{
13 Setiap hari siswa di madrasah ini digembleng bahasa Arab dan bahasa Inggris dan tarjamah kitab yang telah ditentukan jadwalnya dalam satu minggu

${ }^{14}$ Dokumentasi Profil MTsN Kota Madiun

15 Wawancara bersama Wildan, Guru Bahasa Arab pengampu Kelas BLC (Bilingual School), Kepala MTsN kota Madiun, pada hari senin 05 Januari 2016

${ }^{16}$ Wawancara bersama Naning Suhesti, Guru Bahasa Arab pengampu program PDCI School MTsN kota Madiun, pada hari senin 05 Januari 2016
} 

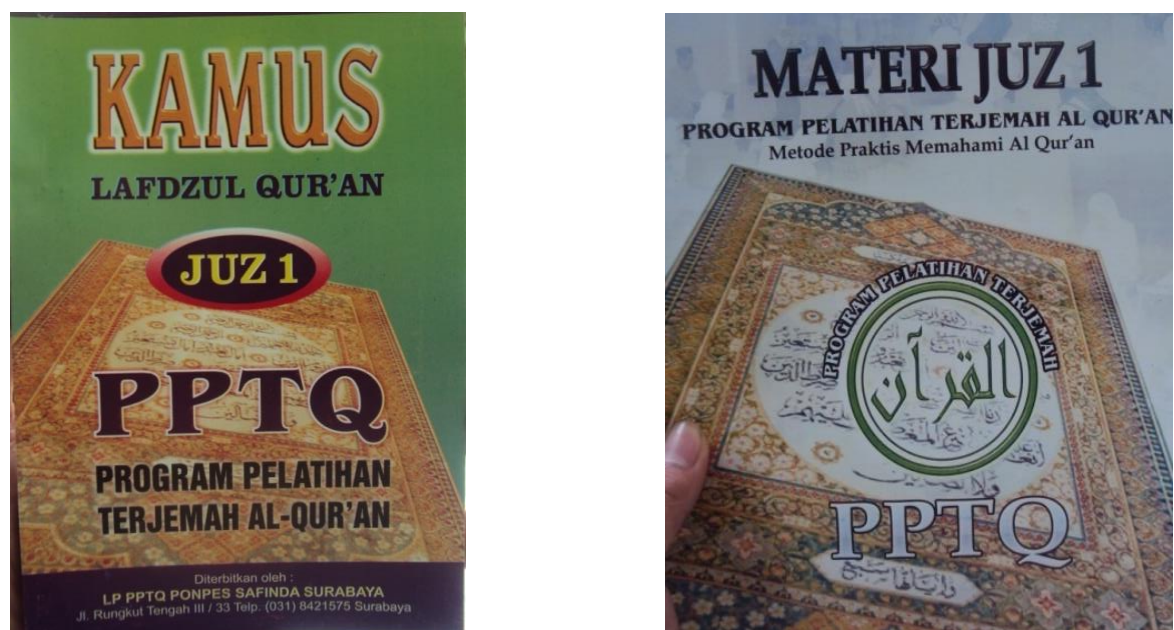

Gambar 2 : Kamus Tambahan di BLC

Gambar 3: Buku Pembelajaran Materi Tarjmah Juz 1

Pendidikan karakter MTs Negeri Kota Madiun pada tahun pelajaran ini difokuskan kepada: religius, disiplin dan peduli lingkungan. Dengan bentuk kegiatan sebagai berikut:

a) Religius

Bentuk kegiatannya adalah: sholah dhuha, sholat dhuhur berjama'ah setiap hari, berjabat tangan dengan guru sebelum masuk kelas, baca qur;an sebelum pelajaran, baca asma'ul husna sebelum pelajaran, takbir keliling Idul Fitri dan Idul Adha, silaturahmi kepada guru atau karyawan pada hari raya Idul Fitri, halal bihalal, qiro'ah, hafalan Al-Qur'an, hafalan Juz Amma (juz 30), latihan qurban, zakat fitrah, kotak amal Jum'at, Muhadharah setiap Jum'at pagi, dan remaja masjid.

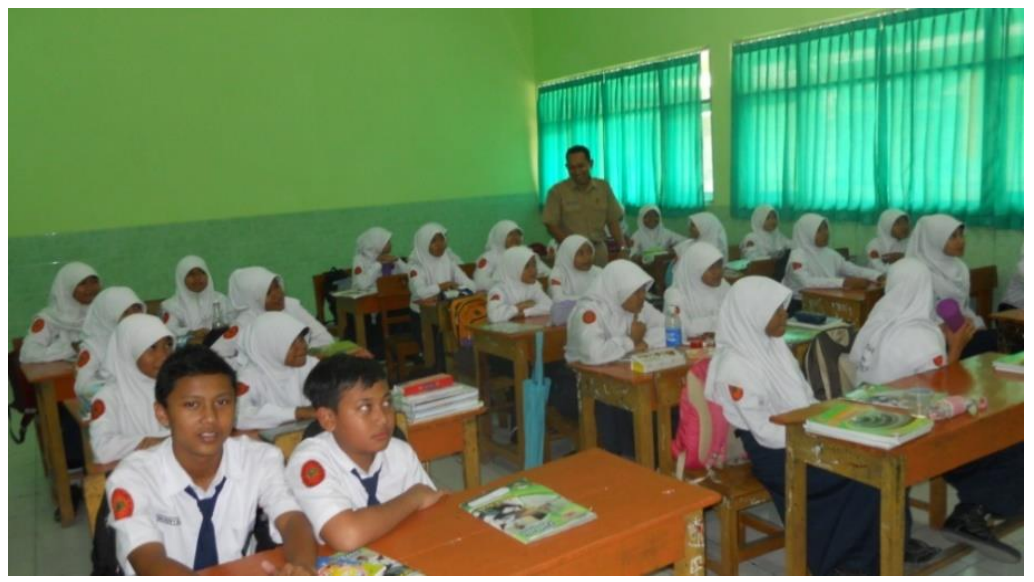

b) Disiplin

Bentuk kegiatannya adalah: upacara bendera, pramuka, perkemahan besar, membuang sampah pada tempatnya, siswa yang melanggar kena poin dan 
sangsi, bel berbunyi pintu pagar ditutup sehingga siswa dan guru terlambat sememtara tidak bisa masuk lokasi madrasah.

c) Peduli Lingkungan

Bentuk kegiatannya adalah: menjaga kebersihan, siswa piket kebersihan sebelum pelajaran dimulai, pemeliharaan taman, membuang sampah pada tempatnya, menjaga kelestarian taman, dan budidaya tanaman hias.

\section{Kemampuan Kemahiran berbahasa Arab siswa kelas BLC (Bilingual School)}

Secara umum, pembelajaran bahasa, termasuk Bahasa Arab, ditujukan untuk melatih empat keterampilan berbahasa yang meliputi keterampilan menyimak (istima'), keterampilan berbicara (kalam), keterampilan membaca (qira'ah), dan keterampilan menulis (kitabah). Masing-masing keterampilan tersebut memiliki karakteristik dan juga target pembelajaran yang berbeda, namun dalam proses pembelajaran, akan sulit memisahkan antara satu keterampilan dengan keterampilan yang lain, karena empat keterampilan tersebut merupakan bagian tak terpisahkan dari pembelajaran bahasa. Dengan kata lain, tidak mungkin melatihkan satu keterampilan tertentu tanpa melatihkan keterampilan yang lain, sekalipun

keterampilan tersebut bukan keterampilan yang akan dilatihkan. Sekalipun demikian, hal ini tidak perlu menimbulkan kebingungan bagi guru yang akan menyelenggarakan pembelajaran Bahasa Arab, karena situasi tersebut merupakan suatu situasi dan juga proses yang alamiah, bahwa pada saat orang sedang berbahasa (ataupun belajar berbahasa), maka seluruh aspek kebahasaan akan berperan dan saling menunjang dalam aktivitas tersebut, antara satu keterampilan dengan keterampilan yang lain.

\section{Problematika Pembelajaran Bahasa Arab di kelas BLC (Bilingual School)}

Pembelajaran bahasa Arab di kelas BLC (Bilingual Bahasa) di MTsN kota Madiun sebagian besar sudah mengarah kepada model pembelajaran PAIKEM, dengan metode mengajar yang bervariasi, dan hasilnya sebagian besar siswa dapat melampaui nilai KKM. Pembelajaran di kategorikan berhasil apabila semua siswa dapat menerima dan memahami materi yang disajikan oleh guru. Materi pelajaran dapat diterima oleh siswa apabila penyajiannya mengikuti prinsip-prinsip 
pembelajaran yang ada,sehingga siswa dapat tuntas dalam menerima pelajaran, dibuktikan dengan hasil evaluasi. ${ }^{17}$

Standarisasi atau taraf keberhasilan dalam belajar mengajar adalah sebagai berikut:

a. Istimewa (maksimal), apabila seluruh bahan pelajaran yang diajarkan dapat dikuasai siswa.

b. Baik sekali (optimal), apabila sebagian besar 76\%-99\% bahan pelajaran dikuasai siswa.

c. Baik (minimal), apabila bahan pelajaran yang diajarkan hanya $60 \%-75 \%$ yang dikuasai siswa.

d. Kurang, apabila bahan pelajaran yang diajarkan kurang dari 60\% yang dapat dikuasai oleh siswa. ${ }^{18}$

1) Problem Linguistik

a) Kurang mengenali bentuk atau tulisan huruf Arab dari beberapa siswa di kelas VIII masih ada beberapa siswa yang belum lancar membaca huruf Arab, bahkan ada yang sama sekali tidak mengenali huruf Arab sambung (tidak bisa baca) namun dia mahir berbahasa Inggris

b) Kesulitan dalam merangkai atau menyambung huruf Arab pengamatan saat kerja kelompok menunjukkan hasil tulisan siswa masih belum benar, baik bentuk huruf maupun cara menyambung huruf. ${ }^{19}$

c) Siswa kesulitan dalam imla' atau menulis Arab dengan dikte Pada saat guru menyuruh siswa untuk menulis Arab dengan dikte, beberapa siswa masih harus dibantu dengan penulisan huruf abjad. Sebagai contoh ketika guru mengucapkan kalimat

2) Problem Non-Linguistik

a) Siswa

Secara umum Pembelajaran bahasa Arab di MTsN kota Madiun dari faktor siswa tidak mengalami problematika yang berarti.

17 Observasi pada tanggal 15 Juni 2016 1996), 121.

18 Syaiful Bahri, “Djamarah Dan Azwan Zain, Strategi Belajar Mengajar” (Jakarta: Rineka Cipta,

19 Wawancara bersama Andre Susanto siswa Kelas BLC (Bilingual School) MTsN kota Madiun, pada 15 Juni 2016 
"Bapak Sigit menjelaskan: "Secara umum Kegiatan Belajar Mengajar KBM) bahasa Arab yang sudah berjalan selama ini sangat kondusif, apalagi di kelas ungulan, hampir tidak ada problem, dengan KKM $75^{20}$

Hal senada juga dikatakan oleh salah satu siswa kelas VII B:

"Indah yang mengatakan bahwa dia sangat senang belajar bahasa Arab, karena materi yang diajarkan sangat mudah difahami. Pada semester I tahun pelajaran2015/2016 dengan KKM yang dipatok 75 dari madrasah dia meraih nilai raport $90^{\prime \prime 21}$

Problematika pembelajaran bahasa Arab yang penulis temukan di MTsN kebanyakan terdapat di kelas regular bukan di kelas BLC 22

b) Latar belakang pendidikan siswa yang heterogen MTsn Kota Madiun $60 \%$ berasal dari masyarakat biasa, hanya sebagian kecil yang tinggal di pesantren, sehingga mereka yang tinggal dimasyarakat/rumah orang tua khususnya yang alumni Sekolah Dasar banyak yang sama sekali belum pernah mengenal bahasa Arab. ${ }^{23}$

c) Kurangnya Motivasi siswa

Belajar atau menguasai bahasa ibu adalah sesuatu yang sangat vital dalam kehidupan manusia. Sebab, tergantung kepada keterampilan Berbahasa itulah keperluan Hidupnya dapat terpenuhi dan keinginannya dapat diraih. Begitu juga keadaan dirinya seperti sakit, sedang marah, atau senang, dapat diketahui orang lain. Jadi, semua itu tidak akan bisa diketahui orang lain tanpa diungkapkan dalam bahasa yang tepat. Dengan demikian motivasi yang mendorong peserta didik untuk mempelajari bahasa orang-orang yang ada di sekitarnyamerupakan motivasi intrinsik yang menjadikan belajar bahasa ibu merupakan tuntutan yang tidak bisa ditawar-tawar lagi dan menjadi suatu keharusan untuk memenuhi kebutuhan hidup danmencapai tujuan akhir. ${ }^{24}$

d) Guru

Kurang/jarang menggunakan alat/media pembelajaran. Salah satu fungsi utama media pembelajaran adalah sebagai alat bantu mengajar yang

${ }^{20}$ Wawancara bersama Indah Sholicah, siswi kelas BLC (Bilingual School) MTsN kota Madiun, pada 15 Juni 2016

${ }^{21}$ Ibid

${ }^{22}$ Lihat Dokumentasi Tulisan MTsN Kota Madiun

23 Wawancara bersama Naning Suhesti, Guru Bahasa Arab pengampu program PDCI School MTsN kota Madiun, pada 15 Juni 2016

${ }^{24}$ Wawancara bersama Titik Wahdati, Guru Bahasa Arab pengampu program BLC School dan Reguler MTsN kota Madiun, pada 15 Juni 2016 
turut mempengaruhi kondisi pemahaman pembelajar tentang materi yang diajarkan. Guru sangat sedikit menggunakan pengantar bahasa Arab saat KBM guru dalam bermuhadatsah masih kurang, ${ }^{25}$ maka dalam pembelajaran pun guru bahsa Arab jarang sekali menggunakan pengantar bahasa Arab dalam pembelajaran.

Namun pada jam tambahanya pukul 14.30 sd 16.00 guru sudah baik pengantarnya mengunakan bahasa Arab karena tenaga pengajar Lulusan AlAzhar Mesir. ${ }^{26}$

e) Lingkungan

Lingkungan tempat belajar bahasa ibu sangat mendukung sekali, karena ia belajar bahasa di lingkungan bahasa itu digunakan dan berada di tengah-tengah orang-orang yang menggunakannya. Dalam hal ini tidak diperoleh oleh peserta didik yang sedang belajar bahasaArab di madrasah, sebab biasanya bahasa Arab diajarkan bukan dilingkungan tempat bahasa itu dipakai dalam percakapan sehari-hari.

f) Madrasah

Madrasah, yang semua menyatakan bahwa di lingkungan sekolah seperti kantor, perpustakaan dan masjid tidak dijumpai percakapan berbahasa Arab atau tulisan-tulisan yang berbahasa Arab. Berbeda masyarakat, dengan lingkungan sekolah keluarga (asrama) dan lingkungan merupakan lingkungan pendidikan yang terarah, teratur dan terencana. Lingkungan ini meliputi semua aspek yang terkait dalam proses belajar mengajar. Sekolah yang mewajibkan para siswanya menggunkan bahasa Arab untuk setiap harinya dapat dipastikan akan membantu kemajuan siswasiswanya dalam menguasai bahasa Arab baik secara aktif maupun pasif. Dengan demikian berdasarkan observasi dan berbagai pihak yang peneliti lakukan di MTsN belum menjumpai hal yang demikian. ${ }^{27}$ Hal ini dikarenakan beberapa faktor diantanya adalah walaupun sekolah berciri khaskan Islam, namun belum mewajibkan siswanya berbahasa Arab setiap harinya sebagai

${ }^{25}$ Wawancara bersama Andre susanto siswa Kelas BLC (Bilingual School) MTsN kota Madiun, pada 15 Juni 2016

${ }^{26}$ Wawancara bersama Wildan, Guru Bahasa Arab pengampu Kelas BLC (Bilingual School), Kepala MTsN kota Madiun, pada hari senin pada 15 Juni 2016

${ }^{27}$ Hasil pengamatan penulis adanya fasilitas penunjang untuk memperkuat bahasa masih di butuhkan yang terutama bersifat intensif asrama ataupun ma'had. 
bahasatersebut. Dan seandainya resmi dilingkungan ada yang menggunakan bahasa Arab sebagai alat komunikasi antar siswa dengan siswa, siswa dengan guru, hal ini sifatnya hanya suka rela. Guru dan karyawan madrasah ini juga berasal dari latar belakang pendidikan yang berbeda sehingga jika peraturan berbahasa diwajibkan akan menyulitkan mereka dalam berinteraksi dengan siswa maupun guru dan karyawan lain. ${ }^{28}$

\section{Simpulan}

Pembelajaran di kelas Bilingual Scholl (BLC) mengedepankan bahasa sebagai sarana efektif mencetak generasi yang mahir berbahasa. Berbasis penggunaan bahasa Inggris dan bahasa Arab dalam pembelajaranya kelas ini efektif dan banyak dibidik oleh para siswa. Kelas Bilingual Scholl (BLC) mengunakan Kurikulum 2013 dengan pembelajaran Matematika dan IPA wajib menggunakan Bahasa Inggris, pembelajaran agama mengunakan bahasa Arab dan Indonesia serta seluruh mata pelajaran berbasis TI (Teknik Informatika) dan waktu pembelajaran dimulai pukul 06.45 sampai dengan pukul 13.30, dilanjutkan dengan intensif belajar sampai pukul 15.30 serta 15 menit sebelum pembelajaran kegiatan English Day dan Arabic Yaumiyyah, Penulis dapat menganalisa bahwasanya alasan digunakannya pembelajaran dengan bahasa asing (bahasa Arab) pada kelas BLC Bllingual School di Madrasah Tsanawiyah Negeri Kota Madiun adalah untuk mencetak ulama yang intelek serta mampu berinteraksi dengan keterampilan bahasa yang ia miliki dengan cara dapat belajar bangsa asing sesuai dengan keterampilan bahasa asing yang dimilikinya serta kemampuan bahasa pada kelas BLC (Bllingual School) sudah bisa dikatakan cukup bagus pada tataran kelas VIII peserta didik akan bertambah kemampuan bahasanya ketika nanti naik kelas VIII dan IX.

\section{Daftar Pustaka}

Azzahra, Siti Fatimah. "Penyusunan Kamus Kedokteran Arab-Indonesia Dengan Pendekatan Linguistik Korpus." Tsaqofiya: Jurnal Pendidikan Bahasa Dan Sastra Arab 2, no. 2 (2020): 168-74.

Bahri, Syaiful. “Djamarah Dan Azwan Zain, Strategi Belajar Mengajar.” Jakarta: Rineka Cipta, 1996.

\footnotetext{
${ }_{28}$ Wawancara bersama Naning Suhesti, Guru Bahasa Arab pengampu program PDCI School MTsN kota Madiun, pada 15 Juni 2016
} 
Hazimī, Muhammad Ibn Mar'ì al. "Daurah Al Shayfiyah Al Tsāniyah Li Mu'alimi Al Lughoh Al 'Arabiyyah Fī Jāmi'at Al Indūnisiyah Wa Al Mudarris Al Singhāliyah, Tadrīs Mahārāt Lughawiyah.” Makkah: Jāmi'ah Umu Al Qurā, n.d.

Heubener, Theodore. "Audio-Visual Techniques in Teaching Foreign Languages.” New York: Cambridge University Press, 1960.

j Lexi, Moeloeng. "Metodologi Penelitian Kualitatif." Bandung: PT. Remaja Rosda Karya, 2001.

Prawiradilaga, Dewi Salma. "Prinsip Desain Pembelajaran (Instructional Design Principles), Jakarta: Kencana Prenada Media Group." Cetakan Kedua, 2007.

Sugiyono, P Dr. "Metode Penelitian Pendidikan: Pendekatan Kuantitatif, Kualitatif, R\&D (Cetakan Ke).” Bandung: CV Alfabeta, 2012.

Syafe'i, Isop. "Implementasi Media Bahasa Dalam Pembelajaran Mahārat Al-Kalām Berdasarkan Fungsi Media Pembelajaran Menurut Kemp Dan Dayton." Tsaqofiya: Jurnal Pendidikan Bahasa Dan Sastra Arab 2, no. 2 (2020): 152-67.

Syamsuddin, A R. "Metode Penelitian Pendidikan Bahasa." Bandung: Remaja Rosdakarya, 2009. 